\title{
KARAKTERISTIK DAN SIFAT FISIKO-KIMIA BERBAGAI KUALITAS KEMENYAN DI SUMATERA UTARA
}

\section{(Characteristics and Physico-chemical Properties of Benzoin Gum Qualities in North Sumatera)}

\author{
Oleh/By : \\ Totok K. Waluyo ${ }^{1)}$, Poedji Hastoeti ${ }^{2)}$ \& T. Prihatiningsih ${ }^{3)}$
}

\begin{abstract}
North Sumatera has long been the center of benzoin gum products in Indonesia. The existing gum in the market can be categorized into 6 qualities, i.e. I, II, until VI, based on the sizes (lump orflakes) and colors.

The experiment looked into the difeence in physico-chemical properties of various benzoin gum qualities with their common varieties, existing in the market. In this way, expectedly, the grouping of beñoin gum qualities can later be improved using the elements of its physical-chemical properties. The properties observed are moisture, impurities, ash and balsamic acid content as well as colors, forms, sizes and melting point.

Results of analysis suggested that moisture content and ash content were relatively similar among those qualities of I, II, III, IV and V. Impurities and melting point were also similar among the qualities of I, II, III and IV. There have been no different in balsamic acid content among the qualities of I, II and III. It can be suggested that the quality of benzoin gum has to be simplified into 4 qualities, i.e. Quality I originated from the former qualities of I until III, quality II from the former quality of $I V$, quality III from the former quality of $V$, and quality IV from the former quality of $V I$.
\end{abstract}

Keywords : Qualities, benzoin gum, physico-chemical properties, balsamic acid.

\section{ABSTRAK}

Sumatera Utara merupakan sentra produksi kemenyan di Indonesia. Kemenyan di pasaran dikelompokkan menjadi 6 kualitas berdasarkan kriteria uji ukuran (besar kecilnya) lempengan/ bongkahan dan warna kemenyan, yaitu kualitas I s/d VI.

Tujuan penelitian ini dimaksudkan untuk mengetahui perbedaan sifat fisiko-kimia kemenyan berbagai kualitas yang ada di pasaran, sehingga diharapkan nantinya pengelompokkan kualitas kemenyan dapat dipertimbangkan secara kuantitatif berdasarkan unsur-unsur sifat fisiko-kimianya. Sifat fisiko-kimia kemenyan yang diuji adalah warna, bentuk, ukuran, kadar air, kadar kotoran, kadar abu, titik lunak dan kadar asam balsamat.

\footnotetext{
${ }^{1)}$ Peneliti pada Pusat Penelitian dan Pengembangan Hasil Hutan, Bogor

2) Teknisi pada Pusat Penelitian dan Pengembangan Hasil Hutan, Bogor

${ }^{3)}$ FMIPA Jurusan Kimia, Universitas Jenderal Sudirman, Purwokerto
} 
Hasil analisa menunjukkan bahwa kadar air dan kadar abu relatif sama antara kemenyan kualitas I, II, III, IV dan V. Kadar kotoran dan titik lunak kemenyan kualitas I, II, III dan IV adalah relatif sama, sedangkan kadar asam balsamat kemenyan kualitas I, II dan III relatif sama. Dengan demikian disarankan pembagian kualitas kemenyan menjadi 4 kelas kualitas yaitu kualitas I berasal dari kemenyan kualitas I s/d III, kualitas II berasal dari kemenyan kualitas IV, kualitas III berasal dari kemenyan kualitas V dan kualitas IV berasal dari kemenyan kualitas VI.

Kata kunci : Kualitas, kemenyan, sifat fisik-kimia, asam balsamat.

\section{PENDAHULUAN}

Sumatera Utara dikenal sebagai daerah penghasil kemenyan terbesar di Indonesia. Daerah-daerah penghasil kemenyan berada di kabupaten Tapanuli Utara, Dairi, Toba Samosir dan Tapanuli Tengah. Kabupaten Tapanuli Utara merupakan sentra produksi kemenyan Sumatera Utara yang mempunyai luas tanaman kemenyan \pm 22.670 ha dengan produksi 2.000 ton/tahun (Sasmuko, 1999). Daerah ini dapat melibatkan petani kemenyan \pm 14 ribu jiwa yang tersebar di 8 kecamatan serta 161 desa (Anonim, 2001).

Pada umumnya kemenyan asal Sumatera Utara diperdagangkan dalam bentuk kepingan/bongkahan yang tidak merata besarnya, sedangkan kualitas maupun tingkat harga ditentukan secara visual seperti besar kecilnya kepingan, warna, bau, kebersihan dan kerapuhannya. Kualitas kemenyan terendah berupa serbuk yang disebut " kemenyan abu “ dengan harga yang terendah di pasaran. Kemenyan berkualitas tinggi (kemenyan putih) umumnya diekspor ke Perancis, Taiwan, Jepang dan Singapura (Edison, et al., 1983).

Di pasaran Sumatera Utara, ada 6 kualitas kemenyan yang diperdagangkan yaitu kualitas I s/d VI. Pembagian kualitas didasarkan pada besar kecilnya bongkahan kemenyan. Sebagai contoh, kemenyan kualitas I berwarna putih sampai putih kekuningan, berdiameter lebih besar dari $2 \mathrm{~cm}$, sedangkan kualitas II berwarna putih sampai putih kekuningan dengan diameter 1 - 2 cm. (Edison, et al., 1983). Dengan demikian pembagian kualitas kemenyan hanya berdasarkan penampilan fisik.

Tulisan ini bertujuan untuk mengetahui perbedaan sifat fisiko-kimia berbagai kualitas kemenyan di pasaran Sumatera Utara. Hasil penelitian ini diharapkan dapat digunakan sebagai acuan kriteria uji dalam menentukan kualitas kemenyan secara kuantitatif.

\section{BAHAN DAN METODE}

\section{A. Bahan}

Bahan yang digunakan dalam penelitian ini adalah 6 kualitas kemenyan yang ada di pasaran. Kemenyan tersebut dikumpulkan dari 2 pedagang besar di kabupaten Tapanuli Utara, Sumatera Utara.

\section{B. Metode Penelitian}

Metode penelitian yang digunakan adalah pengamatan secara visual dan analisa sifat fisiko-kimia kemenyan serta identifikasi asam balsamat. 
1. Pengamatan secara visual

Sifat kemenyan yang diamati secara visual mencakup warna, ukuran dan bentuknya.

\section{Analisa sifat fisiko-kimia}

Kriteria uji sifat fisiko-kimia masing-masing kualitas kemenyan meliputi kadar air, kadar abu, kadar kotoran, titik lunak dan kadar asam balsamat.

Prosedur analisa sifat fisiko-kimia kemenyan sebagai berikut (Anonim, 1972):

a. Kadar air.

Sampel kemenyan seberat 5 gram dimasukkan ke dalam erlenmeyer $300 \mathrm{ml}$ dan ditambahkan pelarut xylene 100 - $150 \mathrm{ml}$. Selanjutnya Erlenmeyer dihubungkan dengan alat Aufhauser dan dipanaskan sampai air dalam sampel keluar semuanya. Jumlah air yang keluar dibaca pada skala yang ada pada alat Aufhauser.

b. Kadar abu

Sampel kemenyan seberat 3 gram dimasukkan ke cawan porselen yang sudah diketahui beratnya. Selanjutnya dimasukkan ke tanur dengan suhu $\pm 625^{\circ} \mathrm{C}$ sampai menjadi abu. Cawan didinginkan dan ditimbang sampai berat tetap. Kadar abu dihitung dengan rumus :

$$
\begin{array}{cl}
\text { Kadar abu } & =\frac{(\mathrm{W} 1-\mathrm{W})}{(\mathrm{W} 2-\mathrm{W})} \times 100 \% \\
\text { Di mana }: & \mathrm{W}=\text { Berat cawan kosong. } \\
\mathrm{W} 1=\text { Berat cawan }+ \text { abu } \\
\mathrm{W} 2=\text { Berat cawan }+ \text { kemenyan }
\end{array}
$$

c. Kadar kotoran

Sebanyak 2 gram kemenyan dimasukkan ke dalam erlenmeyer $100 \mathrm{ml}$ dan dilarutkan dengan $25 \mathrm{ml}$ etanol 90\%, selanjutnya disaring dengan kertas saring. Residu dicuci dengan etanol 90\% hangat lalu dikeringkan pada suhu $100^{\circ} \mathrm{C}$ sekitar 6 jam hingga berat tetap. Kadar kotoran dihitung dengan rumus :

d. Titik lunak

$$
\begin{aligned}
& \text { Kadar abu }=\frac{(\mathrm{W} 1-\mathrm{W} 2)}{\mathrm{W}} \times 100 \% \\
& \text { Di mana: } \mathrm{W}=\text { Berat contoh uji } \\
& \mathrm{W} 1=\text { Berat kertas saring + bahan tak larut etanol } 90 \% \\
& \mathrm{~W} 2=\text { Berat kertas saring. }
\end{aligned}
$$

Sebanyak 30 gram serbuk halus kemenyan dilelehkan, kemudian dimasukkan ke dalam cincin (ring) hingga rata permukaannya. Setelah dingin cincin berisi contoh uji diletakkan pada penahan cincin dan bola baja standar ditempatkan di atas cincin tersebut. Cincin, bola 
baja dan thermometer dimasukkan ke dalam gelas piala berisi air $+800 \mathrm{ml}$, selanjutnya dipanaskan hingga kemenyan melunak dan bola baja akan turun secara perlahan hingga menyentuh dasar alat tersebut. Titik lunak ditentukan berdasarkan suhu dari hasil pembacaan pada thermometer sewaktu bola jatuh menyentuh dasar alat.

e. Kadar asam balsamat

Kemenyan ditimbang sebanyak 1,5 gram dimasukkan ke dalam Erlenmeyer dan ditambahkan $25 \mathrm{ml}$ larutan kalium hidroksida dan etanol 0,5 $\mathrm{N}$ selama 1 jam. Etanol diuapkan sedangkan sisanya dilarutkan dengan $50 \mathrm{ml}$ air panas hingga homogen dan didinginkan. Setelah dingin, ditambahkan $80 \mathrm{ml}$ air dan larutan 1,5 gram magnesium sulfat dalam $50 \mathrm{ml}$ air diaduk rata, didiamkan selama 10 menit. Selanjutnya disaring dan residu dicuci dengan $20 \mathrm{ml}$ air. Filtrat dan cairan hasil pencucian dikumpulkan dan diasamkan dengan $15 \mathrm{ml} \mathrm{HCl} \mathrm{30 \%} \mathrm{(v/v).} \mathrm{Setelah} \mathrm{diasamkan,} \mathrm{diekstraksi} \mathrm{dengan} 40 \mathrm{ml}$ eter sebanyak 4 kali. Lapisan air dibuang, ekstrak eter yang diperoleh dikumpulkan untuk diekstraksi bertahap dengan $70 \mathrm{ml}$ larutan natrium bikarbonat 5\% b/v. Lapisan air yang diperoleh dikumpulkan lalu diekstraksi dengan $20 \mathrm{ml}$ eter. Lapisan eter dibuang, sedangkan lapisan air diasamkan dengan $\mathrm{HCl} \mathrm{30 \%} \mathrm{(v/v)} \mathrm{lalu} \mathrm{dikocok} \mathrm{secara} \mathrm{bertahap} \mathrm{dengan} 80 \mathrm{ml}$ kloroform. Lapisan kloroform diuapkan dengan aliran udara. Residu dilarutkan dalam $10 \mathrm{ml}$ etanol (95\%) hangat yang telah dinetralkan dan didinginkan. Setelah dingin larutan ditambah indikator fenolftalin dan dititrasi dengan $\mathrm{NaOH} 0,1 \mathrm{~N}$. Tiap $\mathrm{ml} \mathrm{NaOH} 0,1 \mathrm{~N}$ setara dengan $14,82 \mathrm{mg}$ asam balsamat.

Kadar asam balsamat dihitung sebagai asam sinamat dengan rumus :

$$
\begin{gathered}
\mathrm{A}=\mathrm{V} \times 14,82 \\
\text { Di mana }: \mathrm{A}=\text { kadar asam balsamat sebagai asam sinamat (mg) } \\
\mathrm{V}=\text { Volume } \mathrm{NaOH} 0,1 \mathrm{~N}
\end{gathered}
$$

3. Identifikasi asam balsamat

a. Analisa infra merah (IR)

Asam balsamat digerus bersama dengan KBr hingga campuran homogen, selanjutnya campuran tersebut dimasukkan ke alat IR untuk dianalisa.

b. Analisa kromatografi lapis tipis (KLT)

Asam balsamat dilarutkan dalam kloroform, selanjutnya larutan tersebut diteteskan pada awal pelat KLT dan dibiarkan hingga kloroform menguap. Campuran eluen dijenuhkan dalam bejana lalu pelat KLT dimasukkan. Setelah eluen mencapai garis akhir, elusi dihentikan dan pelat dikeringkan dari eluen. Spot yang terbentuk dilihat di bawah lampu Ultra Violet (UV) dan nilai Rf dihitung dengan rumus :

$$
\mathrm{Rf}=\text { jarak tempuh spot/jarak tempuh eluen. }
$$

Campuran eluen yang digunakan untuk pengujian ini adalah campuran etil asetat dan nheksana. Ada 6 campuran eluen dengan perbandingan etil asetat:n-heksana yaitu $1: 9 ; 1: 1$; $3: 2 ; 7: 3 ; 8: 2$ dan $1: 0$. 


\section{Analisa Data}

Data masing-masing sifat kemenyan diolah menggunakan Rancangan Acak Lengkap dengan satu faktor yaitu kualitas kemenyan ( I s/d VI ) dengan ulangan sebanyak 5 kali (Mattjik dan Sumertajaya, 2002).

\section{HASIL DAN PEMBAHASAN}

\section{A. Hasil Pengamatan dan Pengukuran Fisik Kemenyan}

Hasil pengamatan dan pengukuran fisik kemenyan Tapanuli Utara tercantum pada Tabel 1. Pembagian kualitas kemenyan Sumatera Utara khususnya di kabupaten Tapanuli Utara, Toba Samosir dan Tapanuli Tengah hanya berdasarkan pada besar kecilnya lempengan/bongkahan kemenyan. Kemenyan kualitas I yang dikenal dengan nama "Mata Kasar" atau "Sidukapi" berupa lempengan besar berukuran lebar $3 \mathrm{~cm}$, panjang $5 \mathrm{~cm}$ dan berwarna putih. Kemenyan kualitas II yang dikenal dengan nama "Mata Halus" berupa lempengan berukuran lebar 2-3 cm, panjang 3-5 cm, berwarna putih dan putih kekuningan.

Kemenyan kualitas I dan II merupakan getah hasil sadapan yang menggumpal/ membeku di bagian antara kulit dan batang pohon kemenyan. Umumnya kemenyan kualitas ini berwarna putih maka disebut kemenyan putih dan merupakan kualitas ekspor (Edison, et al., 1983).

Kemenyan kualitas III berupa lempengan kecil dan butiran. Bentuk lempengan kecil berukuran lebar $2 \mathrm{~cm}$ dan panjang $3 \mathrm{~cm}$, sedangkan bentuk butiran berdiameter $2 \mathrm{~cm}$. Kemenyan lempengan kecil berasal dari bagian antara kulit dan batang sedangkan butiran berasal dari kemenyan yang membeku dibagian luar kulit. Kemenyan dari bagian luar kulit umumnya berwarna kuning sampai coklat kemerahan. Dengan demikian kemenyan kualitas III berwarna putih kekuningan bercampur dengan coklat kemerahan.

Kemenyan kualitas IV, V dan V berbentuk butiran, besar kecilnya butiran yang membedakan kualitas ketiganya dan warna coklat kemerahan. Kemenyan kualitas IV diameter butiran 1-2 cm, kualitas $\mathrm{V}$ diameter butiran $1 \mathrm{~cm}$ dan kualitas VI yang disebut kemenyan abu bentuknya halus seperti butiran gula pasir. 
Tabel 1. Pengamatan dan pengukuran fisik kemenyan Table 1. Observation and physical measurement on benzoin gum

\begin{tabular}{|c|c|c|c|c|}
\hline \multirow{2}{*}{ No. } & \multirow{2}{*}{$\begin{array}{c}\text { Kualitas } \\
\text { kemenyan } \\
\text { (Benzoin gum } \\
\text { quality) } \\
\end{array}$} & \multicolumn{3}{|c|}{$\begin{array}{l}\text { Sifat-sifat kemenyan } \\
\text { (Benzoin gum properties) }\end{array}$} \\
\hline & & Warna (Color) & Bentuk (Form) & Ukuran (Size) \\
\hline 1. & I & $\begin{array}{l}\text { putih } \\
\text { (white) }\end{array}$ & $\begin{array}{l}\text { lempengan } \\
\text { (flake) }\end{array}$ & $\begin{array}{c}\text { lebar }(\text { witdh }) \geq 3 \mathrm{~cm} \\
\text { panjang }(\text { length }) \geq 5 \mathrm{~cm}\end{array}$ \\
\hline 2. & II & $\begin{array}{l}\text { putih sampai putih } \\
\text { kekuningan } \\
\text { (white to yellowish white) }\end{array}$ & $\begin{array}{l}\text { lempengan } \\
\text { (flake) }\end{array}$ & $\begin{array}{c}\text { lebar (witdh) } 2-3 \mathrm{~cm} \\
\text { panjang (length) } 3-5 \mathrm{~cm}\end{array}$ \\
\hline 3. & III & $\begin{array}{l}\text { kuning dan coklat } \\
\text { kemerahan } \\
\text { (yellow and reddish } \\
\text { brown) }\end{array}$ & $\begin{array}{c}\text { lempengan kecil } \\
\text { dan butiran } \\
\text { ((flake and grains) }\end{array}$ & $\begin{array}{c}\text { diameter (diameter) } \geq 2 \mathrm{~cm} \\
\text { lebar (witdh) } \leq 2 \mathrm{~cm} \\
\text { panjang (length) } \leq 3 \mathrm{~cm}\end{array}$ \\
\hline 4. & IV & $\begin{array}{l}\text { kuning kemerahan } \\
\text { (reddish yellow) }\end{array}$ & $\begin{array}{l}\text { butiran } \\
\text { (grains) }\end{array}$ & $\begin{array}{c}\text { diameter } 1-2 \mathrm{~cm} \\
\text { (diameter) }\end{array}$ \\
\hline 5. & $\mathrm{~V}$ & $\begin{array}{l}\text { coklat kemerahan } \\
\text { (reddish brown) }\end{array}$ & $\begin{array}{l}\text { butiran } \\
\text { (grains) }\end{array}$ & $\begin{array}{c}\text { diameter }<1 \mathrm{~cm} \\
\text { (diameter) }\end{array}$ \\
\hline 6. & VI & $\begin{array}{l}\text { Coklat kemerahan } \\
\text { (reddish brown) }\end{array}$ & $\begin{array}{l}\text { butiran } \\
\text { (grains) }\end{array}$ & $\begin{array}{l}\text { halus } \\
\text { (fines) }\end{array}$ \\
\hline
\end{tabular}

\section{B. Analisa Sifat Fisiko-kimia Kemenyan}

Ikhtisar hasil analisa kadar air, kadar abu, kadar kotoran, titik leleh dan kadar asam balsamat kemenyan tercantum pada Tabel 2. Pada umumnya kemenyan kualitas I mempunyai sifat yang lebih baik dibandingkan kualitas lainnya (II, III, IV, V dan VI) terutama kadar abu, kadar kotoran, titik leleh dan besarnya kandungan asam balsamat. Sedangkan kemenyan kualitas VI mempunyai sifat yang terendah dibandingkan kualitas lainnya.

Kemenyan kualitas II mempunyai sifat fisiko-kimia yang tidak selalu lebih baik dibanding kemenyan kualitas III, IV dan V. Sebagai contoh kemenyan kualitas III dan V kadar abu 0,11\% yang lebih kecil dibandingkan dengan kemenyan kualitas II dengan kadar abu 0,15\%. Dengan demikian kemenyan kualitas II tidak mutlak mencerminkan kualitas lebih baik dibandingkan kemenyan kualitas III, IV dan V. 


\section{Tabel 2. Sifat fisiko-kimia kemenyan}

\section{Table 2. Physico-chemical properties of benzoin gum}

\begin{tabular}{|c|c|c|c|c|c|c|c|}
\hline \multirow{3}{*}{ No } & \multirow{3}{*}{$\begin{array}{c}\text { Sifat fisiko-kimia } \\
\text { (Physico-chemical } \\
\text { properties) }\end{array}$} & \multicolumn{6}{|c|}{ Kualitas (Quality) } \\
\hline & & I & II & III & IV & V & VI \\
\hline & & $(X \pm S)$ & $(X \pm S)$ & $(X \pm S)$ & $(X \pm S)$ & $(\mathrm{X} \pm \mathrm{S})$ & $(X \pm S)$ \\
\hline 1. & $\begin{array}{l}\text { Kadar air } \\
\text { (Moisture contents), } \\
\%\end{array}$ & $2,30 \pm 0,27$ & $2,40 \pm 0,34$ & $2,28 \pm 0,27$ & $2,22 \pm 0,34$ & $2,14 \pm 0,16$ & $3,10 \pm 0,10$ \\
\hline 2. & $\begin{array}{l}\text { Kadar abu } \\
\text { (Ash contents), \% }\end{array}$ & $0,06 \pm 0,02$ & $0,15 \pm 0,02$ & $0,11 \pm 0,03$ & $0,17 \pm 0,02$ & $0,11 \pm 0,01$ & $1,67 \pm 0,06$ \\
\hline 3. & $\begin{array}{l}\text { Kadar kotoran } \\
\text { (Impurities), \% }\end{array}$ & $3,05 \pm 0,51$ & $3,88 \pm 0,38$ & $3,83 \pm 0,20$ & $3,67 \pm 0,42$ & $6,08 \pm 0,45$ & $11,47 \pm 0,76$ \\
\hline 4. & $\begin{array}{l}\text { Titik leleh } \\
\text { (Melting point), }{ }^{\circ} \mathrm{C}\end{array}$ & $57,0 \pm 0,40$ & $61,35 \pm 1,25$ & $60,90 \pm 2,33$ & $67,40 \pm 3,46$ & $69,50 \pm 4,18$ & $83,55 \pm 2,95$ \\
\hline 5. & $\begin{array}{l}\text { Kadar asam } \\
\text { Balsamat } \\
\text { (Balsamic acid } \\
\text { contents), \% }\end{array}$ & $33,73 \pm 2,57$ & $33,87 \pm 6,17$ & $32,80 \pm 3,71$ & $31,05 \pm 6,59$ & $31,90 \pm 0,82$ & $24,98 \pm 2,69$ \\
\hline
\end{tabular}

Keterangan (Remarks): $\mathrm{X}=$ nilai rata-rata dari 5 ulangan (mean value of five replications);

$\mathrm{S}=$ simpangan baku (standard deviation)

Kadar air terendah pada kemenyan kualitas V, hal ini terjadi disebabkan butiran kemenyan relatif kecil sehingga mudah untuk dikeringkan, sedangkan kemenyan kualitas I dan II dengan bentuk lempengan yang relatif besar akan lebih sulit dikeringkan.

Kadar abu, kadar kotoran dan titik leleh kemenyan kualitas I lebih rendah dibandingkan kemenyan kualitas lainnya. Hal ini dimungkinkan kemenyan kualitas I mempunyai kemurnian cukup tinggi karena getah berasal dari bagian antara kulit dan batang yang terlindung sehingga tidak terpengaruh lingkungan.

Untuk mengetahui adanya perbedaan sifat fisiko-kimia kemenyan dari berbagai kualitas selanjutnya dilakukan sidik ragam (Tabel 3) yang hasilnya menunjukkan bahwa perbedaan kualitas kemenyan berpengaruh sangat nyata terhadap sifat fisiko-kimia (kadar air, kadar abu, kadar kotoran, titik leleh dan kadar kandungan asam balsamat). Analisis lanjutan dengan uji Tuckey (Tabel 4.) menunjukkan kadar air kemenyan kualitas I, II, III. IV dan V tidak berbeda nyata, sedangkan kemenyan kualitas VI mempunyai kadar air yang relatif tinggi dibanding kualitas lainnya. Hal ini dimungkinkan karena kemenyan kualitas VI berupa serbuk halus sehingga mudah menyerap air dibandingkan kemenyan yang bentuknya berupa lempengan/ bongkahan atau berupa butiran kasar seperti kualitas I s/d V.

Kadar abu kemenyan kualitas I, II, III, IV dan V tidak berbeda nyata sedangkan kadar abu tertinggi adalah kemenyan kualitas VI. Kadar abu menunjukkan jumlah mineral dalam suatu bahan. Bahan-bahan organik akan terbakar dan menguap pada saat pemanasan, sedangkan bahan-bahan anorganik akan tertinggal sebagai abu (Winarno, 1987). Dengan demikian tingkat kemurnian kemenyan kualitas I s/d V relatif sama. 
Kadar kotoran dihitung sebagai bahan yang tidak larut dalam etanol. Kadar kotoran kemenyan kualitas I, II, III dan IV tidak berbeda nyata dan terendah dibanding kualitas V dan VI. Makin rendah kualitas kemenyan makin tinggi pula kadar kotorannya, karena kemenyan makin kecil ukurannya sehingga makin sulit dilakukan pemisahan kemenyan dengan kotorankotoran yang ada. Kotoran kemenyan dapat berupa serpihan kulit, tanah dan lain-lain.

Titik leleh menunjukkan tingkat kemurnian suatu bahan. Kemenyan kualitas I, II, III dan IV tidak berbeda nyata dan kualitas V dan VI tidak berbeda nyata. Dengan demikian kemenyan kualitas I, II, III dan IV lebih murni dibanding kualitas V dan VI.

\section{Tabel 3. Analisa sidik ragam sifat fisiko-kimia kemenyan}

\section{Table 3. Analysis of variance on physico-chemical properties of benzoin gum}

\begin{tabular}{|c|c|c|c|c|}
\hline $\begin{array}{l}\text { Sunber keragaman } \\
\text { (Source of variation) }\end{array}$ & $\begin{array}{l}\text { Derajad bebas } \\
\text { (Degrees of freedom) }\end{array}$ & $\begin{array}{l}\text { Jumlah kuadrat } \\
\text { (Sum squares) }\end{array}$ & $\begin{array}{l}\text { Kuadrat tangah } \\
\text { (Mean square) }\end{array}$ & $\begin{array}{l}\text { F hitung } \\
(F \text { calculated })\end{array}$ \\
\hline $\begin{array}{l}\text { 1. Kadar air (Moisture contents), \% } \\
\text { - Perlakuan (Treatments) } \\
\text { - Galat (Error) } \\
\text { - Total }\end{array}$ & $\begin{array}{c}5 \\
24 \\
29\end{array}$ & $\begin{array}{l}4,0320 \\
1,1945 \\
5,2265\end{array}$ & $\begin{array}{l}0,8064 \\
0,0497\end{array}$ & 16,22 ** \\
\hline $\begin{array}{l}\text { 2. } \text { Kadar abu (Ash contents), \% } \\
\text { - Perlakuan (Treatments) } \\
\text { - Galat (Error) } \\
\text { - Total }\end{array}$ & $\begin{array}{c}5 \\
24 \\
29\end{array}$ & $\begin{array}{c}9,9651 \\
0,1568 \\
10,1219\end{array}$ & $\begin{array}{l}1,9930 \\
0,0065\end{array}$ & 305,07 ** \\
\hline $\begin{array}{l}\text { 3. Kadar kotoran (Impurities), \% } \\
\text { - Perlakuan (Treatments) } \\
\text { - Galat (Error) } \\
\text { - Total }\end{array}$ & $\begin{array}{c}5 \\
24 \\
29\end{array}$ & $\begin{array}{c}252,5240 \\
5,6560 \\
258,1800\end{array}$ & $\begin{array}{r}50,5048 \\
1,1312\end{array}$ & $44,65 * *$ \\
\hline $\begin{array}{l}\text { 4. Titik leleh (Melting point), }{ }^{\circ} \mathrm{C} \\
\text { - Perlakuan (Treatments) } \\
\text { - Galat (Error) } \\
\text { - Total }\end{array}$ & $\begin{array}{c}5 \\
24 \\
29\end{array}$ & $\begin{array}{c}2229,493 \\
177,025 \\
2406,518\end{array}$ & $\begin{array}{r}445,898 \\
7,376\end{array}$ & $60,45 * *$ \\
\hline $\begin{array}{l}\text { 5. Kadar asam balsamat (Balsamic } \\
\text { acid contents), \% } \\
\text { - Perlakuan (Treatments) } \\
\text { - Galat (Error) } \\
\text { - Total }\end{array}$ & $\begin{array}{c}5 \\
24 \\
29\end{array}$ & $\begin{array}{l}275,3809 \\
438,9905 \\
714,3714\end{array}$ & $\begin{array}{l}55,0761 \\
18,2912\end{array}$ & $3,01 *$ \\
\hline
\end{tabular}

Asam balsamat merupakan komponen kimia utama dari kemenyan. Makin tinggi kadar asam balsamat yang terkandung dalam kemenyan makin tinggi pula kualitas kemenyan tersebut. Kadar asam balsamat kemenyan kualitas I, II dan III tidak berbeda nyata dan tertinggi dibanding kualitas lainnya. Sedangkan kualitas IV dan V tidak berbeda nyata dan kadar asam balsamatnya masih lebih tinggi dibanding kualitas VI. 
Tabel 4. Uji Tuckey sifat fisiko-kimia kemenyan

Table 4. Tuckey's test on physico-chemical properties of benzoin gum

\begin{tabular}{|c|c|c|c|c|c|c|}
\hline $\begin{array}{c}\text { Sifat fisiko-kimia } \\
\text { (Physico-chemical properties) }\end{array}$ & & & & & & \\
\hline $\begin{array}{l}\text { 1. Kadar air (Moisture contents), \% } \\
\text { Kualitas (Quality) } \\
\text { Rata-rata (Mean) } \\
\text { Uji Tuckey (Tuckey's test) }\end{array}$ & $\begin{array}{c}\mathrm{V} \\
2,14 \\
\end{array}$ & $\begin{array}{c}\text { IV } \\
2,22\end{array}$ & $\begin{array}{c}\text { III } \\
2,28\end{array}$ & $\begin{array}{c}\mathrm{I} \\
2,30\end{array}$ & $\begin{array}{c}\text { II } \\
2,40\end{array}$ & $\begin{array}{c}\mathrm{VI} \\
3,00\end{array}$ \\
\hline $\begin{array}{l}\text { 2. Kadar abu (Ash contents), \% } \\
\text { Kualitas (Quality) } \\
\text { Rata-rata (Mean) } \\
\text { Uji Tuckey (Tuckey's test) }\end{array}$ & $\begin{array}{c}\mathrm{I} \\
0,06 \\
\end{array}$ & $\begin{array}{c}\mathrm{III} \\
0,11\end{array}$ & $\begin{array}{c}\mathrm{V} \\
0,11\end{array}$ & $\begin{array}{c}\text { II } \\
0,15\end{array}$ & $\begin{array}{c}\text { IV } \\
0,17\end{array}$ & $\begin{array}{c}\text { VI } \\
1,67\end{array}$ \\
\hline $\begin{array}{l}\text { 3. Kadar kotoran (Impurities), \% } \\
\text { Kualitas (Quality) } \\
\text { Rata-rata (Mean) } \\
\text { Uji Tuckey (Tuckey's test) }\end{array}$ & $\begin{array}{c}\mathrm{I} \\
3,05\end{array}$ & $\begin{array}{l}\text { IV } \\
3,67\end{array}$ & $\begin{array}{c}\text { III } \\
3,83\end{array}$ & $\begin{array}{c}\text { II } \\
3,89\end{array}$ & $\begin{array}{c}\mathrm{V} \\
6,08\end{array}$ & $\begin{array}{c}\text { VI } \\
11,47\end{array}$ \\
\hline $\begin{array}{l}\text { 4. Titik leleh (Melting point), }{ }^{\circ} \mathrm{C} \\
\text { Kualitas (Quality) } \\
\text { Rata-rata (Mean) } \\
\text { Uji Tuckey (Tuckey's test) }\end{array}$ & $\begin{array}{c}\mathrm{I} \\
57,0\end{array}$ & $\begin{array}{c}\text { III } \\
60,90\end{array}$ & $\begin{array}{c}\text { II } \\
61,35\end{array}$ & $\begin{array}{c}\text { IV } \\
67,40\end{array}$ & $\begin{array}{c}\mathrm{V} \\
69,50\end{array}$ & $\begin{array}{c}\text { VI } \\
83,55\end{array}$ \\
\hline $\begin{array}{l}\text { 5. Kadar asam balsamat (Balsamic } \\
\text { acid), \% } \\
\text { Kualitas (Quality) } \\
\text { Rata-rata (Mean) } \\
\text { Uji Tuckey (Tuckey's test) }\end{array}$ & $\begin{array}{c}\text { II } \\
33,87\end{array}$ & $\begin{array}{c}\mathrm{I} \\
33,73\end{array}$ & $\begin{array}{c}\text { III } \\
32,80\end{array}$ & $\begin{array}{c}\mathrm{V} \\
31,90\end{array}$ & $\begin{array}{c}\text { IV } \\
31,05\end{array}$ & $\begin{array}{c}\text { VI } \\
24,98\end{array}$ \\
\hline
\end{tabular}

Asam balsamat merupakan komponen utama kemenyan, maka kadar asam balsamat menjadi unsur utama untuk pengelompokan kualitas kemenyan dan diikuti sifat-sifat lainnya seperti kadar air, kadar abu, kadar kotoran dan titik leleh. Dengan demikian kemenyan kualitas I, II dan III yang ada di pasaran seharusnya digolongkan kualitas I, kualitas IV menjadi kualitas II, kualitas V menjadi kualitas III dan kualitas VI menjadi kualitas IV.

Apabila sifat fisiko-kimia kemenyan kualitas I s/d VI yang ada di pasaran dipadukan dengan Standar Industri Indonesia (SII) 2044-87 tentang kemenyan (Tabel 5) maka hasilnya seperti tercantum pada Tabel 6 .

Warna kemenyan kualitas I dan II di pasaran masuk kualitas I berdasarkan SII karena syaratnya berwarna putih kekuning-kuningan, sedangkan kemenyan kualitas III s/d VI berwarna coklat kemerahan dapat masuk kualitas II berdasarkan SII karena kualitas II tidak ditetapkan persyaratan warna. 
Kadar air kemenyan kualitas I s/d VI di pasaran memenuhi syarat kualitas I (SII), hal ini disebabkan oleh pengeringan kemenyan yang dilakukan oleh masyarakat cukup lama yaitu sekitar 3 bulan sehingga kadar air kemenyan di pasaran cukup rendah.

Kadar abu kemenyan kualitas I s/d V di pasaran masuk kualitas I (SII), sedangkan kualitas VI masuk kualitas II (SII). Hal ini menunjukkan bahwa kemenyan yang ada di pasaran mempunyai tingkat kemurnian tinggi.

Kadar kotoran kemenyan kualitas I s/d IV di pasaran masuk kualitas II (SII), sedangkan kualitas VI tidak masuk standar. Kalau dilihat dari kadar abu di atas, kemenyan yang ada di pasaran mempunyai tingkat kemurnian relatif tinggi. Hal ini disebabkan SII kemenyan untuk kadar kotoran persyaratannya cukup tinggi.

Kadar asam balsamat kemenyan kualitas I s/d V masuk kualitas I (SII). Kemenyan kualitas VI tidak memenuhi SII, keadaan ini disebabkan kadar abu dan kadar kotorannya relatif tinggi sehingga akan mempengaruhi kadar asam balsamat yang terkandung didalamnya.

Tabel 5. Standar Mutu Kemenyan (SII 2044-87)

Table.5. Quality standard of benzoin gum (SII 2044-87)

\begin{tabular}{|c|l|c|c|}
\hline \multirow{2}{*}{ No } & \multicolumn{1}{|c|}{$\begin{array}{c}\text { Kriteria } \\
\text { (Criteria) }\end{array}$} & \multicolumn{2}{|c|}{ Syarat (Condition) } \\
\cline { 2 - 4 } & \multicolumn{1}{|c|}{$\begin{array}{c}\text { Mutu I } \\
\text { (Quality) }\end{array}$} & $\begin{array}{c}\text { Mutu II } \\
\text { (Quality) }\end{array}$ \\
\hline 1. & Warna (Color) & $\begin{array}{c}\text { Putih kekuning-kuningan } \\
\text { (Yellowish white) }\end{array}$ & -- \\
2. & Kadar air (Moisture contents), \% & Maks. 10 & Maks. 10 \\
3. & Kadar abu (Ash contents), \% & Maks. 1,0 & Maks. 2,0 \\
4. & Kadar kotoran (Impurities), \% & Maks. 1,0 & Maks. 5,0 \\
5. & Kadar asam balsamat (Balsamic acid & Min. 30,0 & Min. 25,0 \\
\hline
\end{tabular}


Tabel 6. Klasifikasi kemenyan kualitas lokal berdasarkan SII 2044-87 Table 6. Classificasion of benzoin gum quality based on SII 2044-87

\begin{tabular}{|c|c|c|c|c|c|c|c|}
\hline \multirow{2}{*}{\multicolumn{2}{|c|}{\begin{tabular}{|c} 
\\
No. \\
Nifat fisiko- \\
kimia \\
(Physico-chemical \\
properties)
\end{tabular}}} & \multicolumn{6}{|c|}{ Kualitas kemenyan (Benqoin gum quality) } \\
\hline & & I & II & III & IV & V & VI \\
\hline 1. & $\begin{array}{l}\text { Warna } \\
\text { (Color) }\end{array}$ & $\begin{array}{l}\text { Putih } \\
\text { (White) }\end{array}$ & $\begin{array}{l}\text { Putih dan } \\
\text { putih } \\
\text { kekuningan } \\
\text { (White and } \\
\text { yellowish white) }\end{array}$ & $\begin{array}{c}\text { Putih } \\
\text { kekuningan } \\
\text { dan coklat } \\
\text { kemerahan } \\
\text { (Yellowish white } \\
\text { and reddish } \\
\text { brown) }\end{array}$ & $\begin{array}{c}\text { Coklat } \\
\text { kemerahan } \\
\text { (Reddish } \\
\text { brown) }\end{array}$ & $\begin{array}{c}\text { Coklat } \\
\text { kemerahan } \\
\text { (Reddish } \\
\text { brown) }\end{array}$ & $\begin{array}{l}\text { Coklat } \\
\text { kemerahan } \\
\text { (Reddish } \\
\text { brown) }\end{array}$ \\
\hline & SII 2044-87 & I & I & -- & -- & -- & -- \\
\hline 2. & $\begin{array}{l}\text { Kadar air } \\
\text { (Moisture } \\
\text { contents), \% } \\
\text { SII 2044-87 }\end{array}$ & 2,30 & 2,40 & 2,28 & 2,22 & 2,14 & 3,10 \\
\hline 3. & $\begin{array}{l}\text { Kadar abu } \\
(\text { Ash contents), \% } \\
\text { SII } 2044-87\end{array}$ & $\begin{array}{c}0,06 \\
\text { I }\end{array}$ & $\begin{array}{c}0,15 \\
\text { I }\end{array}$ & $\begin{array}{c}0,11 \\
\text { I }\end{array}$ & $\begin{array}{c}0,17 \\
\mathrm{I}\end{array}$ & $\begin{array}{c}0,11 \\
\mathrm{I}\end{array}$ & $\begin{array}{c}1,67 \\
\text { II }\end{array}$ \\
\hline 4. & $\begin{array}{l}\text { Kadar kotoran } \\
\text { (Impurities), \% } \\
\text { SII 2044-87 }\end{array}$ & $\begin{array}{c}3,05 \\
\text { II }\end{array}$ & $\begin{array}{c}3,88 \\
\text { II }\end{array}$ & $\begin{array}{c}3,83 \\
\text { II }\end{array}$ & $\begin{array}{c}3,67 \\
\text { II }\end{array}$ & $\begin{array}{l}6,08 \\
\text { tmk }\end{array}$ & $\begin{array}{l}11,47 \\
\mathrm{tmk}\end{array}$ \\
\hline 5. & $\begin{array}{l}\text { Kadar asam } \\
\text { Balsamat } \\
\text { (Balsamic acid } \\
\text { contents), \% } \\
\text { SII 2044-87 }\end{array}$ & 33,73 & 33,87 & 32,80 & 31,05 & 31,90 & 24,98 \\
\hline
\end{tabular}

Keterangan (Remarks) : tmk =Ttidak masuk kualifikasi berdasarkan SII 2044-87 (Not qualified based on SII 2044-87) 


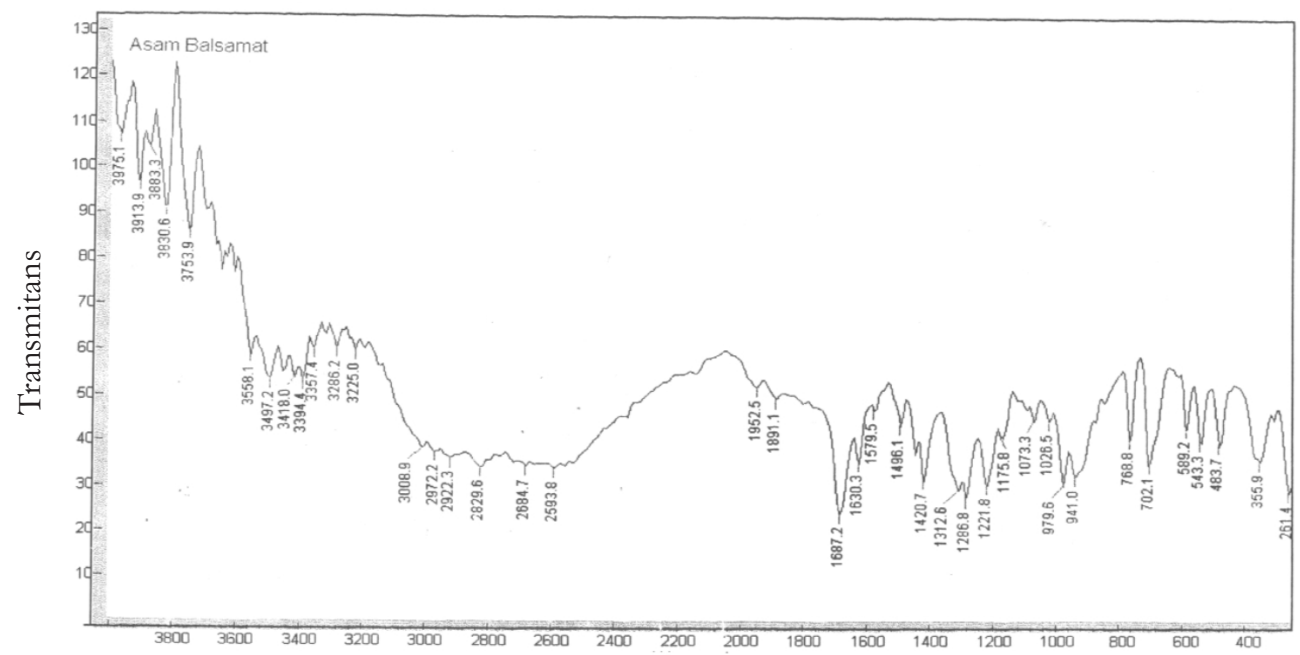

Bilangan gelombang (Wave number) $\mathrm{cm}-1$

Gambar 1. Spektra IR kristal asam balsamat

Figure 1. IR spectra of balsamic acic crystal

Berdasarkan spektra IR dari kristal asam balsamat (Gambar 1) memberikan informasi serapan tajam pada daerah 1687,2 $\mathrm{cm}^{-1}$ yang menunjukkan ikatan $\mathrm{C}=\mathrm{O}$ (karbonil) terkonjugasi. Fessenden dan Fessenden (1986) menyatakan resapan $\mathrm{C}=\mathrm{O}$ (karbonil) berada di daerah $1700-1725 \mathrm{~cm}^{-1}$, namun dengan adanya konjugasi menyebabkan serapan bergeser ke daerah lebih rendah yaitu $1680-1700 \mathrm{~cm}^{-1}$. Serapan khas yang lebar mulai daerah $3300 \mathrm{~cm}^{-1}$ merupakan serapan khas untuk ikatan O-H karboksilat. Lebih lanjut Fessenden dan Fessenden (1986) menyatakan asam karboksilat akan membentuk dimer berikatan hydrogen, yang menyebabkan serapan $\mathrm{O}-\mathrm{H}$ asam-asam karboksilat sangat lebar dan intensif, serapan $\mathrm{O}-\mathrm{H}$ ini mulai sekitar $3300 \mathrm{~cm}^{-1}$ dan melandai ke daerah serapan $\mathrm{C}-\mathrm{H}$ alifatik. Adanya gugus asam karboksilat juga didukung dengan serapan pada sidik jari antara lain pada $1221,8 \mathrm{~cm}^{-1}$ yang merupakan serapan uluran C-O karboksilat, sedangkan serapan pada 1312,6 cm $\mathrm{cm}^{-1}$ ang menunjukkan tekukan O-H dari dimer asam karboksilat. Serapan pada $1630,3 \mathrm{~cm}^{-1}$ menunjukkan ikatan $\mathrm{C}=\mathrm{C}$ sp. Uluran ikatan rangkap $\mathrm{C}=\mathrm{C}$ menimbulkan serapan pada 1600 $1700 \mathrm{~cm}^{-1}$ yang lemah dan hanya 1/100 - 1/10 lebih rendah dari serapan gugus karbonil. Alkena memiliki serapan lemah dekat $1650 \mathrm{~cm}^{-1}$ (Sastrohamidjojo, 2001). Serapan antara 800 $1000 \mathrm{~cm}^{-1}$ diduga merupakan serapan untuk $=\mathrm{C}-\mathrm{H}$ alkenil. Ikatan karbon hidrogen alkenil menunjukkan absorbsi tekukan dalam daerah sidik jari IR. Deretan 4 pita serapan yang muncul di daerah 1400 - $1600 \mathrm{~cm}^{-1}$ menunjukkan bahwa dalam sampel terdapat cincin benzena. Fessenden dan Fessenden (1986) menyatakan absorbsi untuk vibrasi C-C aril (benzena) menimbulkan deretan 4 puncak, namun keempat puncak tersebut tidak selalu tampak. 
Dua puncak tajam di daerah $700-800 \mathrm{~cm}^{-1}$ menunjukkan bahwa cincin benzena mengikat satu substituen (benzena monosubstitusi). Data serapan di atas memberikan informasi bahwa kristal asam balsamat dalam kemenyan diperkirakan terdapat senyawa dengan gugus asam karboksilat terkonjugasi, gugus benzena monosubstitusi dan terdapat gugus alkena.

Hasil analisa KLT terhadap asam balsamat bertujuan untuk mengetahui jumlah komponen yang terdapat dalam asam balsamat getah kemenyan. Hasil KLT dengan perbandingan eluen etil asetat dan n-heksana 1:9 menghasilkan satu spot dengan Rf 0,125 yang dapat dilihat di bawah lampu UV. Dengan menggunakan berbagai perbandingan eluen lainnya, asam balsamat juga menghasilkan satu spot saja seperti terlihat pada Gambar 2. Hasil tersebut menunjukkan bahwa asam balsamat terdiri dari satu komponen yaitu asam sinamat.

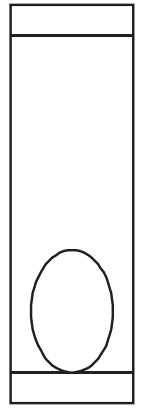

a

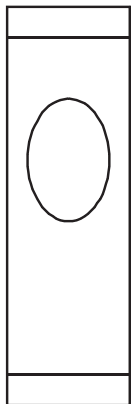

$\mathrm{b}$

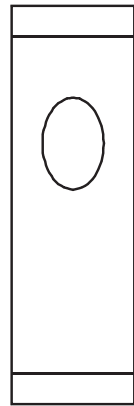

$\mathrm{C}$

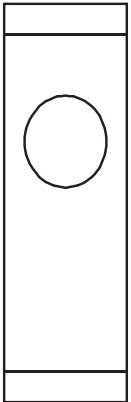

$\mathrm{d}$

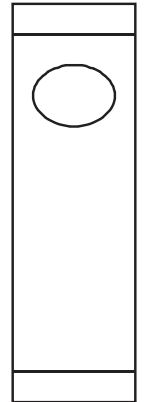

e

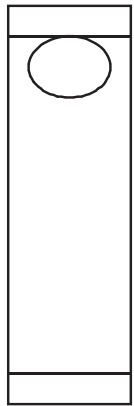

f

Gambar 2. Spot hasil KLT kristal asam balsamat

Figure 2. Detected spot appeared from TLC (thin-layer chromatography) analysis on balsamic acid crystal

Keterangan (Remarks) : a. Perbandingan etil asetat dengan n-heksana

(Comparison between ethyl acetate and $n$-hexane $)=1: 9 ; \mathrm{Rf}=0,125$

b. Perbandingan etil asetat dengan n-heksana

(Comparison between ethyl acetate and $n$-hexane) $=1: 1: \mathrm{Rf}=0,7$

c. Perbandingan etil asetat dengan n-heksana

(Comparison between ethyl acetate and $n$-hexane) $=3: 2 ; \mathrm{Rf}=0,65$

d. Perbandingan etil asetat dengan n-heksana

(Comparison between ethyl acetate and $n$-hexane) $=7: 3 ; \mathrm{Rf}=0,75$

e. Perbandingan etil asetat dengan $n$-heksana

(Comparison between ethyl acetate and $n$-hexane $)=8: 2 ; \mathrm{Rf}=0,825$

f. Perbandingan etil asetat dengan n-heksana

(Comparison between ethyl acetate and $n$-hexane) $=1: 0 ; \mathrm{Rf}=0,875$ 


\section{KESIMPULAN}

Kualitas kemenyan Sumatera Utara dikelompokkan menjadi 6 yaitu kualitas I s/ VI. Warna kemenyan kualitas terbaik yaitu kualitas I berwarna putih. Makin rendah kualitas kemenyan, warna kemenyan putih kekuning-kuningan hingga merah kecoklatan. Demikian juga besarnya bongkahan/lempengan kemenyan makin kecil hingga halus seperti abu.

Kemenyan kualitas I, II, III, IV dan V mempunyai sifat kadar air dan kadar abu yang sama. Kadar kotoran dan titik lunak sama pada kemenyan kualitas I, II, III dan IV. Asam balsamat yang merupakan unsur utama yang terkandung dalam kemenyan, kadarnya sama antara kemenyan kualitas I, II dan III.

Berdasarkan analisa IR dan KLT, asam balsamat yang terkandung dalam kemenyan terdiri dari satu komponen yaitu asam sinamat.

\section{DAFTAR PUSTAKA}

Anonim. 1972. Farmakope Indonesia. Departemen Kesehatan Republik Indonesia. Jakarta.

1987. Kemenyan. Standar Industri Indonesia. Departemen Perindustrian Republik Indonesia.

2001. Kadin Tapanuli Utara Jajaki Pemasaran Kemenyan di P. Jawa. Harian Sinar Indonesia Baru. Medan. No. 8884.

Edison, D.T.; M. Putra dan Alhamra. 1983. Pengembangan Kemenyan. Departemen Perindustrian. Balai Penelitian dan Pengembangan Industri. Medan.

Fessenden, R.J. dan J.S. Fessenden. 1986. Kimia Organik. Jilid I. Edisi III. Erlangga. Jakarta.

Heyne. 1987. Tumbuhan Berguna Indonesia Jilid III. Badan Penelitian dan Pengembangan Kehutanan. Jakarta

Mattjik, A. A. dan I. M. Sumertajaya. 2002. Perancangan Percobaan dengan Aplikasi SAS dan MINITAB. Jilid I. IPB PRESS. Bogor.

Sasmuko, S.A. 1999. Karakteristik Kemenyan Sumatera Utara dan Laos. Prosiding Ekspose Hasil Penelitian Balai Penelitian Kehutanan Pematang Siantar, tanggal 30 Maret 1999 di Medan. Hlm. 57-67. Balai Penelitian Kehutanan, Pematang Siantar.

Sasmuko dan Jayusman. 2000. Resume Hasil-hasil Penelitian Kemenyan. Balai Penelitian Kehutanan Pematang Siantar. Aek Nauli.

Sastrohamidjojo, H. 2001. Dasar-dasar Spektroskopi. Edisi II. Liberty. Yogyakarta.

Winarno, F.G. 1987. Kimia Pangan dan Gizi. Gramedia. Jakarta. 


\section{Lampiran 1. Kemenyan berbagai kualitas}

\section{Appendix 1. Benzoin gum with various quality}

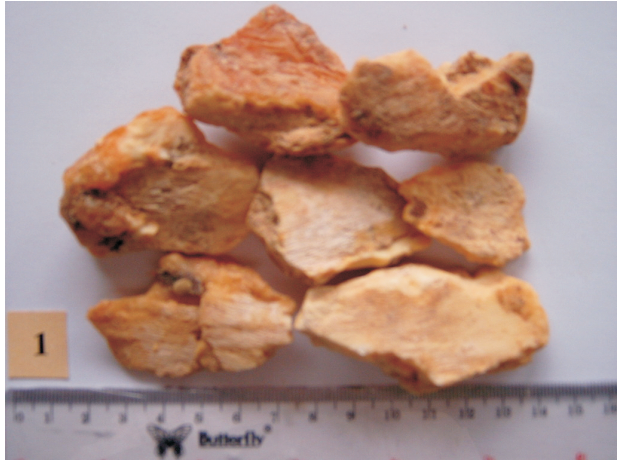

Gambar 3. Kemenyan kualitas I

Figure 3. Benzoin gum of quality I

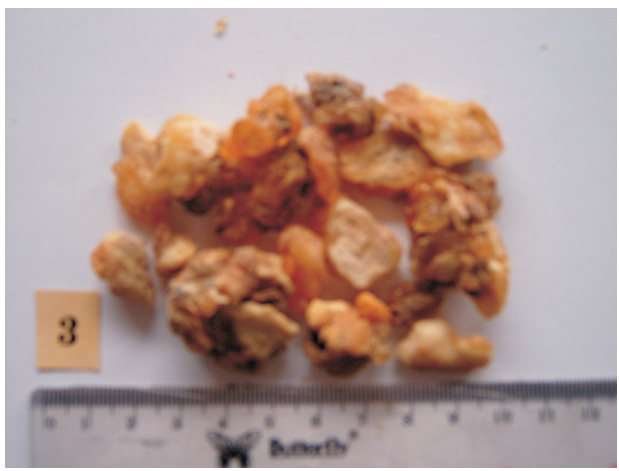

Gambar 5. Kemenyan kualitas III

Figure 5. Benzoin gum of quality III

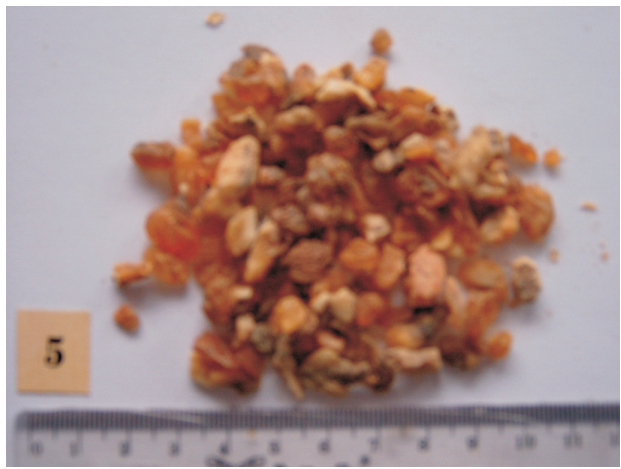

Gambar 7. Kemenyan kualitas V Figure 7. Benzoin gum of quality $V$

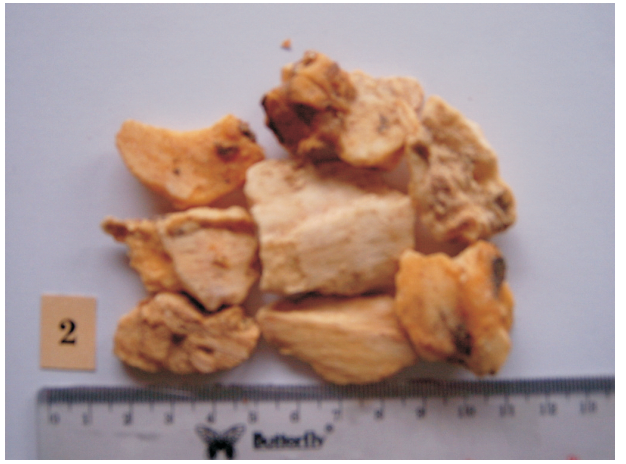

Gambar 4. Kemenyan kualitas II

Figure 4. Benzoin gum of quality II

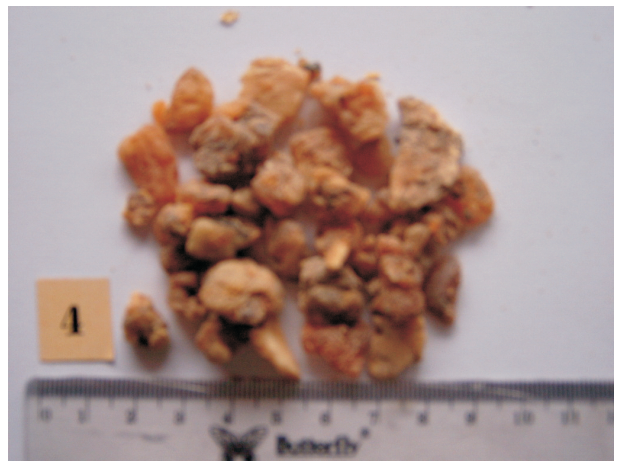

Gambar 6. Kemenyan kualitas IV

Figure 6. Benzoin gum of quality IV

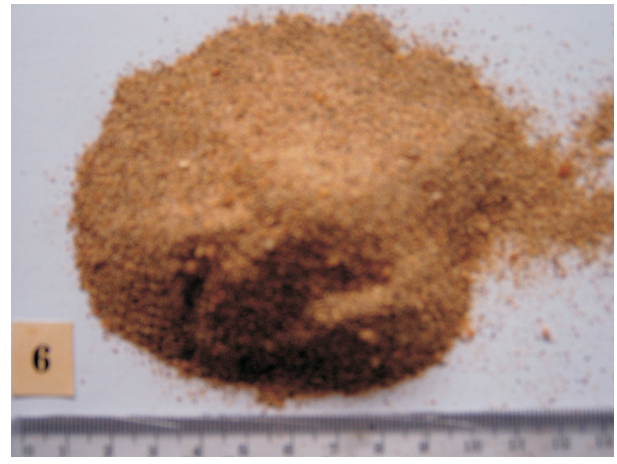

Gambar 8. Kemenyan kualitas VI Figure 8. Benzoin gum of quality VI 